DOI https://doi.org/10.30525/978-9934-26-065-0-17

\author{
Oksana Tsyhanok, \\ Postgraduate Student \\ in the Department of Art Expertise \\ National Academy of Culture and Arts Management \\ ORCID iD: 0000-0001-7161-7268 \\ (c) The Author 2021
}

\title{
DUE DILIGENCE STANDARDS \\ IN THE CIRCULATION OF CULTURAL PROPERTY
}

\begin{abstract}
In the article of values practical problems of legal circulation of cultural property. A range of issues related to the relocation of cultural property from problem areas has been identified. The focus is on an analysis of the meaning of the term 'due diligence standards'. Compliance with due diligence standards is one of the prerequisites that allow to secure the owner against financial, time and reputational losses in the future. The author refers to the international legal instruments which gave rise to the practical application of due diligence standards. Listed the international façade associations that have established and implemented moral codes of conduct based on UNESCO's recommendations.

Keywords: cultural property, due diligence standards, legal circulation, legality of transactions, law norms.

There is an undeniable interest in the ownership of cultural property. The possession of authentic unique objects that carry a cultural meaning is not only prestigious but can also be a great investment opportunity. However, it comes with a lot of risks worth considering, like forgery, theft, over attribution, limitations of ownership rights or even full loss of ownership, risk of damage or destruction, risk of price collapse, and so on.

Some of these risks can be minimized by insurance, but unfortunately not all, and any of the risks mentioned above can potentially lead to a financial loss. When ownership of cultural property is primarily an investment opportunity and the main goal is the profit, then thorough analysis of all risks is absolutely crucial before any purchase.
\end{abstract}


The art market is shrouded in privacy and is notorious for its lack of transparency. Over the past 50 years, the European Union has slowly but steadily increased regulation and control over the circulation of cultural property starting with UNESCO 1970 Convention on the Means of Prohibiting and Preventing the Illicit Import, Export and Transfer of Ownership of Cultural Property [12] and UNIDROIT Convention on stolen or illegally exported cultural objects [14].

The calls for openness, morality and legality of transactions that involve cultural property may be strictly declarative but nonetheless it's a start. This allows the formation of national legal frameworks that enhance control over trade. Even such a stronghold of liberalism as the Geneva Freeport was forced to adopt new rules of the game in 2009. Today there are main international codes of ethics in the field of cultural property: ICOM Code of Ethics for Museums [6] and UNESCO International Code of Ethics for dealers in Cultural property [13]. Almost all significant international professional associations have formulated their own ethical standards in this way: International League of Antiquarian Booksellers [9], Association of International Antiquities Dealers [1], Confédération Internationale des Négociants en Euvres d'Art [4], International Association of Dealers in Ancient Art [2], International Foundation for Art Research [8] etc.

The situation in non-EU countries is different. International law norms are often not incorporated into the national legislation of these countries or are haphazard. The market for cultural property is therefore already completely in limbo. The ethical dimension of the circulation of cultural property is not is not taken into account, given the political and economic situation in these countries. The World Customs Organization reports that Russia and Ukraine are perennial leaders in the illicit movement of cultural property $[15 ; 16 ; 17]$. The focus is on exports, less on imports. These countries are donors of cultural property to the wider European and US markets and/or are transit points for cultural property from other countries. The domestic market for cultural objects is not manageable. This is despite the fact that, for example, Ukraine ratified The 1970 Convention in 1988 and UNIDROIT Convention on stolen or illegally exported cultural objects in 1998.

Probably, this situation is also explained by the loss of the tradition of owning cultural property. During the existence of the Soviet Union, openly possessing and dealing with cultural objects was not only not accepted, but 
also dangerous. The state tried in every way to monopolize the possession of such values. There were very few antique dealerships and they were all state-owned. A small number of collectors and dealers existed exclusively underground. Private trade was considered speculation and punishable by imprisonment and confiscation of property. As there was no official market, the legal sphere that would provide this market did not develop. Related private services (restoration, expertise) were also in the shadows. With this legacy, the former republics withdrew from the Soviet Union and began a period of wild uncivilized circulation of cultural objects.

During the 1990s and early 2000s saw the formation of most of the modern large collections on the territory of the former Soviet Union. The collision is that at times they have been introduced into science, but do not even have an acceptable proof of ownership [11]. The question of the authenticity of objects and the lawful provenance is a matter of great concern. Authenticity is of interest to potential buyers because it is a measure of financial gain and buyers are aware that the market is full of all kinds of counterfeits. Provenance is traditionally not perceived as an element of authentication and is ignored as irrelevant information. This is especially true of archaeological finds. Here is the main law of the market: there is demand, there is supply. As long as the potential financial benefits outweigh the risks, there will be supply and demand for items of dubious origin.

International law explicitly states that standards of due diligence must be observed in the circulation of cultural property $[5 ; 14]$. Let not be detailed, but quite clear. A set of verification actions will protect the buyer from questionable transactions and subsequent legal, financial and reputational problems.

First of all, you should check the market price and reliability of the vendor. The next step is to verify the provenance. It is important that the provenance is documented. But it should be borne in mind that fake documents is a very common phenomenon and if necessary, you should turn to experts for consultations. You should also inquire about the certificate of authenticity and export documents. It is possible the object originates from risk zones - regions that have recently undergone a significant number of illegal excavations (Ukraine, Russia, Middle East, Cyprus, etc.) In this case, you should be careful and check the ICOM Red Lists [7]. In any case, it does not hurt to check the databases of lost / stolen works of art Carabinieri Art Squad [3], INTERPOL [10] and the like. 
It is best if it is possible to carefully examine the object itself, rather than its image or description. If the seller refuses to provide the item for additional independent expertise, it is not recommended to continue the purchase. Inspection and analysis of an object can reveal whether or not it shows signs of recent excavation, has been restored, or if it was part of a larger object, collection, or complex. Such information carries weight in making purchasing decisions, and in determining the fair value of an object. Having thoroughly evaluated the situation, the decision to acquire the item is the full responsibility of the purchaser.

The practice of due diligence is based on common sense. It is better to explore the object in many ways than to enjoy the consequences of your own carelessness. Especially in regions that do not have the best reputation in the moving collections and the transfer of ownership of cultural property.

\section{REFERENCES}

1. AIAD (2016) Code of Conduct http://aiad.org.uk/about-us/code-of-conduct/. Accessed 20 July 2021

2. AIDAA (1993) Code of Ethics and Practice https://iadaa.org/about-us/. Accessed 19 July 2021

3. Carabinieri Art Squad (2021) Endangered \& Stolen objects http://tpcweb.carabinieri.it/SitoPubblico/search. Accessed 15 Aug 2021

4. CINOA (1935) Code of Ethics https://www.cinoa.org/cinoa/codeofethics. Accessed 20 July 2021

5. Council of the European Union (2014) DIRECTIVE 2014/60/EU OF THE EUROPEAN PARLIAMENT AND OF THE COUNCIL of 15 May 2014 on the return of cultural objects unlawfully removed from the territory of a Member State and amending Regulation (EU) No 1024/2012 (Recast). Official Journal of the European Union, 28 May 2014. https://www.obs-traffic.museum/ sites/default/files/ressources/files/EU_Council_directive_2014_60_EU.pdf. Accessed 23 July 2021

6. ICOM General Secretariat (1986, 2004) Code of Ethics https://icom.museum/en/resources/standards-guidelines/code-of-ethics/. Accessed 26 July 2021

7. ICOM General Secretariat (2021) Red Lists https://www.obs-traffic.museum/ fr/international-council-museums. Accessed 26 Aug 2021 
8. IFAR (1969) Provenance Gide https://www.ifar.org/Provenance_Guide.pdf. Accessed 22 July 2021

9. ILAB (1948) Code of Usages and Customs https://ilab.org/page/codescustoms. Accessed 21 July 2021

10. INTERPOL (2021) Stolen Works of Art Database https://www.interpol.int/ How-we-work/Databases/Stolen-Works-of-Art-Database. Accessed 17 Aug 2021

11. PLATAR (1991) Museum of historical cultural heritage PLATAR http://www.platar.org/en. Accessed 26 Aug 2021

12. UNESCO (1970) The 1970 Convention on the Means of Prohibiting and Preventing the Illicit Import, Export and Transfer of Ownership of Cultural Property https://en.unesco.org/fighttrafficking/1970. Accessed 02 Aug 2021

13. UNESCO (1999) International Code of Ethics for Dealers in Cultural Property https://unesdoc.unesco.org/ark:/48223/pf0000121320. Accessed 26 July 2021

14. UNIDROIT (1995) Convention on stolen or illegally exported cultural objects https://www.unidroit.org/instruments/cultural-property/1995-convention/. Accessed 04 Aug 2021

15. WCO (2017) ENFORCEMENT AND COMPLIANCE Illicit Trade Report http://www.wcoomd.org/-/media/wco/public/global/pdf/topics/ enforcement-and-compliance/activities-and-programmes/illicit-tradereport/itr_2017_en.pdf?db=web. Accessed 12 AUG 2021

16. WCO (2018) ENFORCEMENT AND COMPLIANCE Illicit Trade Report http://www.wcoomd.org/-/media/wco/public/global/pdf/topics/ enforcement-and-compliance/activities-and-programmes/illicit-tradereport/itr_2018_en.pdf?db=web. Accessed 12 AUG 2021

17. WCO (2019) ENFORCEMENT AND COMPLIANCE Illicit Trade Report http://www.wcoomd.org/-/media/wco/public/global/pdf/topics/ enforcement-and-compliance/activities-and-programmes/illicit-tradereport/itr_2019_en.pdf?db=web. Accessed 12 Aug 2021 